

Nounjan N et al. (2021)

Notulae Botanicae Horti Agrobotanici Cluj-Napoca

Volume 49, Issue 1, Article number 12130

DOI: $10.15835 /$ nbha 49112130

Research Article

\title{
Spermidine priming promotes germination of deteriorated seeds and reduced salt stressed damage in rice seedlings
}

\author{
Noppawan NOUNJAN, Netnapit KUMON-SA, \\ Piyada THEERAKULPISUT*
}

Khon Kaen University, Faculty of Science, Department of Biology, Salt-tolerant Rice Research Group, Khon Kaen 40002, Thailand; nounjann@gmail.com; netnapit.kumonsa@gmail.com; piythe@kku.ac.th (*correspondingauthor)

\begin{abstract}
Deterioration of seeds is an important problem leading to low germination and uneven crop establishment causing poor crop growth and productivity. Soil salinity is another factor limiting crop cultivation. Spermidine (Spd) is a compound widely reported for diminishing adverse effects of salt stress in plants. In this study, the effects of Spd priming on normal and deteriorated rice seeds were investigated under salt stress during germination and young seedling stages. Rice seeds were primed with $\mathrm{H}_{2} \mathrm{O}$ and Spd solutions for $24 \mathrm{~h}$ before germination. All rice seeds were grown in Petri dishes containing $5 \mathrm{ml}$ of deionized water with 0 (control) or $150 \mathrm{mM} \mathrm{NaCl}$ (salt treatment) for 1-10 d. The results showed that priming groups had higher germination percentage (GP) and germination index (GI) in both normal and deteriorated seeds. Moreover, deteriorated seeds primed with $0.5,1.0$ and $1.5 \mathrm{mM}$ Spd showed significantly higher GP and GI than $\mathrm{H}_{2} \mathrm{O}$ primed and non-primed seeds. During early hours of hydration, Spd-primed seeds produced reactive oxygen species (ROS) faster and at higher level than non-priming and $\mathrm{H}_{2} \mathrm{O}$ priming groups in both control and saline conditions. Earlier accumulation of ROS was associated with more rapid germination. In young seedlings, salinity stress caused a marked decrease in growth and increased membrane damage indicated by higher malondialdehyde (MDA) and electrolyte leakage (EL). Conversely, Spd priming increased growth and reduced membrane damage of rice seedlings established from normal and deteriorated seeds under salt stress. The finding suggested that Spd priming can effectively improve germination of deteriorated seeds and enhance seedling growth under control and salt stress conditions.
\end{abstract}

Keywords: deteriorated seeds; reactive oxygen species; rice; salt stress; seed priming; spermidine

\section{Introduction}

Salinity causes a limitation of plant growth, development and production of crops around the globe. In Thailand, salinity is one of serious problems in agricultural areas and productivity of rice which is a very important economic crop of the country. Rice is sensitive to salt stress especially in early seedling stage. Salt stress induces osmotic stress as a result of water deficit followed by ion toxicity effect resulting from excessive uptake and accumulation of sodium and chloride ions leading to oxidative stress due to high production of reactive oxygen species (ROS) (Munns and Tester, 2008). Generally, ROS such as hydrogen peroxide $\left(\mathrm{H}_{2} \mathrm{O}_{2}\right)$,

Received: 27 Oct 2020. Received in revised form: 27 Jan 2021. Accepted: 29 Jan 2021. Published online: 03 Feb 2021.

From Volume 49, Issue 1, 2021, Notulae Botanicae Horti Agrobotanici Cluj-Napoca journal will use article numbers in place of the traditional method of continuous pagination through the volume. The journal will continue to appear quarterly, as before, with four annual numbers. 
superoxide anion $\left(\mathrm{O}_{2}{ }^{-}\right)$and hydroxyl radical $\left(\mathrm{OH}^{*}\right)$ are by-products produced from normal metabolism processes in chloroplasts, mitochondria and peroxisomes.

In seeds, ROS are produced throughout the life of the seeds from embryogenesis process to the end of germination (Bailly et al., 2008). Mostly, ROS in seeds especially, $\mathrm{O}_{2}{ }^{-*}$ are produced in mitochondria and subsequently dismutated to $\mathrm{H}_{2} \mathrm{O}_{2}$. Several types of enzymes, such as NADPH oxidases, amine oxidases, polyamine oxidases, oxalate oxidases, and a large family of class III peroxidases are contributed to production of $\mathrm{O}_{2}{ }^{\circ}$ and $\mathrm{H}_{2} \mathrm{O}_{2}$ (El-Maarouf-Bouteau et al., 2008; You and Chan, 2015). It has been reported that high ROS production during seed imbibition associated with high NADPH oxidase which occurred in the embryo and in aleurone cells promoted radicle protrusion during seed germination (Ishibashi et al., 2015).

On the other hand, excessive ROS are harmful and easy to interact with other essential molecules resulted in cellular damage. The most damaging process caused by ROS is lipid peroxidation which resulted in membrane damage. Many compounds such as malondialdehyde (MDA) increase significantly from the reaction between polyunsaturated precursors and ROS (Gill and Tuteja, 2010a). Numerous reports from many plant species presented that under salt stress plants accumulated higher $\mathrm{H}_{2} \mathrm{O}_{2}$, malondialdehyde (MDA; an indicator for lipid peroxidation) and electrolyte leakage (EL; an indicator of membrane damage) compared to non-stressed plants (Demidchik et al., 2014; Esfandiari and Gohari, 2017). However, beneficial role of optimum level of ROS has been pointed out. ROS are believed to play a critical role as signal transduction molecules under several stresses (Miller et al., 2010). Low level ROS such as $\mathrm{H}_{2} \mathrm{O}_{2}$ has been reported in controlling the specific biological/physiological processes cascades (such as cell cycle and plant responses to biotic and abiotic stresses) (Sofo et al., 2015). In addition, ROS can participate in transduction of stress signals from chloroplasts to nucleus. ROS trigger protein kinases/protein phosphatases leading to redox hemostasis (Kreslavski et al., 2012).

Seed priming is considered an alternative way for enhancing seed germination and seedling growth. This method is able to enhance stress tolerance (Chen and Arora, 2013). There are several chemical solutions used as priming agent. For example, rice seeds primed with beta-amino butyric acid produced seedlings with enhanced growth, higher chlorophyll content and low MDA level under non-stressed and stressed $(\mathrm{NaCl}$ and polyethylene glycol; PEG) conditions when compared to those of non-priming group (Jisha and Puthur, 2013). Priming rice seed with PEG could increase plant growth parameters and photosynthetic pigments as compared to seeds without PEG priming under nano- $\mathrm{ZnO}$ stress. The results showed that priming rice seeds with PEG could alleviate the toxicity of nano- $\mathrm{ZnO}$ stress and improved the cell structures of leaf and roots in rice (Salah et al., 2015).

Spermidine (Spd), one of polyamines derivatives, is phytohormone-like aliphatic amine natural compounds with aliphatic nitrogen structure (Gill and Tuteja, 2010b). Exogenous Spd and Spd priming have been reported to improve abiotic stress tolerance in plants. Spraying $S p d$ on rice leaves could alleviate oxidative damage by reducing $\mathrm{O}_{2}{ }^{-*}$ production and $\mathrm{H}_{2} \mathrm{O}_{2}$ content under submergence stress (Liu et al., 2015). Spd priming of seeds also induced better expression of genes related to salt stress tolerance such as ion transporter and osmolyte synthesis resulting in up-regulation of several metabolic pathways to defend salt stress (Paul and Roychoudhury, 2017).

In Thailand, farmers commonly store rice seeds for use as seed source for the following growing seasons. Inappropriate storage condition in high humidity and temperature lead to seed deterioration, thus, contributing to reduced seed germination, seeding establishment and growth, and finally decrease in rice yield. Deteriorated seeds may lose their viability, vigour, and quality (Jyoti and Malik, 2013). Thus, to solve problems due to both salinity and deteriorated seeds, Spd was used as priming agent for normal and deteriorated seeds to investigate its role in promoting seed germination and mitigate salt stress effects. 


\section{Materials and Methods}

\section{Seeds preparation}

Thai rice elite cultivar 'Khao Dawk Mali 105' (KDML105) was used in this study (KDML105 rice seeds was provided by Khon Kaen Rice Research Center, Department of Rice, Thailand). Seeds were harvested in November 2016 and stored for 4 months at room temperature before being used in the experiment. Seeds were divided into 2 groups; normal healthy and deteriorated seeds. Deteriorated seeds were prepared following the method modified from Chhetri (2009) by incubating normal seeds under $100 \% \mathrm{RH}$ at $60^{\circ} \mathrm{C}$ for $48 \mathrm{~h}$ and airdried.

\section{Seed priming}

Seeds were surface-sterilized for $10 \mathrm{~min}$ in $2 \%$ sodium hypochlorite and washed three times with distilled water. Seeds were soaked with $\mathrm{H}_{2} \mathrm{O}$ and in different concentrations of $S p d(0.5,1.0$ and $1.5 \mathrm{mM})$ for $24 \mathrm{~h}$, and then washed three times with distilled water. After that, immersed seeds were dehydrated by airdrying until seed moisture content reduced to the same value as that of seeds before priming. Seeds without soaking with $\mathrm{H}_{2} \mathrm{O}$ or $\mathrm{Spd}$ were used as control (non-priming). Ten primed seeds were transferred to sterile filter paper in Petri dishes (90-mm diameter) containing $5 \mathrm{ml}$ of sterilized deionized water (control) or 150 $\mathrm{mM} \mathrm{NaCl}$ (salt treatment). The concentration of $\mathrm{NaCl}$ used in this study followed that by Theerakulpisut et al. (2016). Seeds were incubated in darkness at $25^{\circ} \mathrm{C}$. Each treatment was replicated three times.

\section{Germination test and growth measurement}

Seeds were considered germinated when the radicle was at least $5 \mathrm{~mm}$ long. Germination of seeds was observed daily until $10 \mathrm{~d}$ to calculate GP and GI according to Hussain et al. (2015). GP was the ratio between the number of seeds germinated and the total number of seeds, and expressed as percentage. GI was calculated as (no. of germinated seeds/days of first count $)+\ldots+\ldots . \ldots$ (no. of germinated seeds/days of first count). Root and shoot lenght, and biomass of seedlings were measured at $10 \mathrm{~d}$ after germination. For dry weight, root and shoot were dried in a hot-air oven at $70^{\circ} \mathrm{C}$ for $2 \mathrm{~d}$ until the dry weight was stabilized. Meanwhile, roots and shoots were collected from each group of experiment and stored at $-20^{\circ} \mathrm{C}$ for further analysis.

\section{Histochemical localization of $\mathrm{O}_{2}{ }^{--}$}

Localization of $\mathrm{O}_{2}{ }^{\circ-}$ was done following the method of Chen et al. (2016) with some modifications. After 12, 24, 36 and $48 \mathrm{~h}$ of dehusked seeds imbibition, 5 seeds in each group were stained with $1 \mathrm{mM}$ nitroblue tetrazolium (NBT) for examining $\mathrm{O}_{2}{ }^{--}$. After washing with double-distilled water, stained seeds were photographed using the stereomicroscope (Szx9, Olympus).

\section{Electrolyte leakage (EL) and MDA content}

To determine EL, seedling samples were cut $(0.1 \mathrm{~g})$ and placed in closed vials containing $10 \mathrm{ml}$ of deionized distilled water. The electrical conductivity of the solution was measured using the conductivity meter (Gondo, PL-700PC, Taipei) after incubating at $25^{\circ} \mathrm{C}$ for $24 \mathrm{~h}$ in the dark (EL1). Then, the solution with leaf pieces was boiled $\left(100{ }^{\circ} \mathrm{C}\right)$ for $15 \mathrm{~min}$. After cooling, electrical conductivity of the solution was measured (EL2). EL (\%) was estimated as: (EL1/EL2) × 100. For MDA, seedling samples $(0.1 \mathrm{~g})$ were used to determine MDA content according to the modified method of Heath and Packer (1968). Briefly, $0.1 \mathrm{~g}$ of shoot samples was homogenized with $5 \mathrm{~mL} 0.1 \%$ trichloroacetic acid (TCA), followed by centrifugation at 10,000 g for 20 min. The supernatant $(0.5 \mathrm{ml})$ was mixed with $0.5 \mathrm{~mL} 0.5 \%$ thiobarbituric acid (TBA) in 20\% TCA. The reaction mixture was incubated at $95^{\circ} \mathrm{C}$ for $20 \mathrm{~min}$. The reaction mixture was then incubated on ice to stop the reaction then centrifuge at $10,000 \mathrm{~g}$ for $5 \mathrm{~min}$. Absorbance was read at 532 and $600 \mathrm{~nm}$ using a spectrophotometer. MDA content was calculated using extinction coefficient at $155 \mathrm{mM} \mathrm{cm}^{-1}$. 


\section{Statistical analysis}

Statistical analysis was done using SPSS ver.19. Duncan's multiple range test (DMRT) $(p \leq 0.05)$ was used to determine means of significant difference among the treatments.

\section{Results}

\section{Effects of Spd priming on seed germination}

Priming normal seeds with both $\mathrm{H}_{2} \mathrm{O}$ and Spd showed better GP and GI compared the non-priming group under $\mathrm{NaCl}$ stress (14\% increase in $\mathrm{GP}$ in $\mathrm{H}_{2} \mathrm{O}$ and $0.5 \mathrm{mM}$ Spd priming groups and $25 \%$ increase in 1.0 and $1.5 \mathrm{mM}$ Spd priming groups). Moreover, GI under $\mathrm{NaCl}$ stress of $\mathrm{Spd}$ priming groups increased over $50 \%$. For deteriorated seeds, only Spd priming groups enhanced GP by $22-30 \%$ under normal and $14-25 \%$ in salt treatment conditions compared to non-priming groups. GI of deteriorated seeds treated with $\mathrm{Spd}(0.5,1.0$ and $1.5 \mathrm{mM}$ ) was significantly increased by 28,33 and $50 \%$, respectively under normal condition and 18,32 and $52 \%$, respectively under $\mathrm{NaCl}$ stress (Table 1 ).

Table 1. Germination percentage and germination index of non-priming (control), $\mathrm{H}_{2} \mathrm{O}$ priming and Spd priming of normal and deteriorated rice seeds under normal $\left(\mathrm{H}_{2} \mathrm{O}\right)$ and stress $(\mathrm{NaCl})$ conditions at $10 \mathrm{~d}$

\begin{tabular}{|c|c|c|c|c|c|}
\hline \multirow{2}{*}{$\begin{array}{l}\text { Seed priming } \\
\text { treatment }\end{array}$} & \multirow[b]{2}{*}{ Condition } & \multicolumn{2}{|c|}{ Normal seeds } & \multicolumn{2}{|c|}{ Deteriorated seeds } \\
\hline & & $\begin{array}{c}\text { Germination } \\
(\%)\end{array}$ & $\begin{array}{c}\text { Germination } \\
\text { index }\end{array}$ & $\begin{array}{c}\text { Germination } \\
(\%)\end{array}$ & $\begin{array}{c}\text { Germination } \\
\text { index }\end{array}$ \\
\hline \multirow{2}{*}{$\begin{array}{c}\text { Control } \\
\text { (non-priming) }\end{array}$} & $\mathrm{H}_{2} \mathrm{O}$ & $100 \pm 0.00 \mathrm{a}$ & $3.81 \pm 0.08 \mathrm{c}$ & $70 \pm 5.77 \mathrm{bc}$ & $1.76 \pm 0.03 \mathrm{~d}$ \\
\hline & $\mathrm{NaCl}$ & $60 \pm 0.00 c$ & $0.64 \pm 0.01 \mathrm{f}$ & $60 \pm 10.00 c$ & $0.77 \pm 0.07 \mathrm{~h}$ \\
\hline \multirow{2}{*}{$\mathrm{H}_{2} \mathrm{O}$} & $\mathrm{H}_{2} \mathrm{O}$ & $100 \pm 0.00 \mathrm{a}$ & $4.32 \pm 0.03 b$ & $70 \pm 15.28 \mathrm{bc}$ & $1.86 \pm 0.03 \mathrm{~d}$ \\
\hline & $\mathrm{NaCl}$ & $70 \pm 5.77 b c$ & $0.73 \pm 0.08 \mathrm{f}$ & $60 \pm 5.77 c$ & $0.88 \pm 0.04 \mathrm{gh}$ \\
\hline \multirow{2}{*}{$0.5 \mathrm{mM} \mathrm{Spd}$} & $\mathrm{H}_{2} \mathrm{O}$ & $100 \pm 0.00 \mathrm{a}$ & $5.37 \pm 1.10 \mathrm{a}$ & $90 \pm 10.00 \mathrm{ab}$ & $2.43 \pm 0.04 \mathrm{c}$ \\
\hline & $\mathrm{NaCl}$ & $70 \pm 10.0 \mathrm{bc}$ & $1.53 \pm 0.04 \mathrm{e}$ & $70 \pm 11.55 \mathrm{bc}$ & $0.94 \pm 0.15 \mathrm{~g}$ \\
\hline \multirow{2}{*}{$1.0 \mathrm{mM} \mathrm{Spd}$} & $\mathrm{H}_{2} \mathrm{O}$ & $100 \pm 0.00 \mathrm{a}$ & $5.37 \pm 0.11 \mathrm{a}$ & $100 \pm 0.00 \mathrm{a}$ & $2.63 \pm 0.01 b$ \\
\hline & $\mathrm{NaCl}$ & $80 \pm 0.00 b$ & $1.76 \pm 0.03 \mathrm{e}$ & $70 \pm 11.55 \mathrm{bc}$ & $1.13 \pm 0.03 \mathrm{f}$ \\
\hline \multirow{2}{*}{$1.5 \mathrm{mM}$ Spd } & $\mathrm{H}_{2} \mathrm{O}$ & $100 \pm 0.00 \mathrm{a}$ & $5.67 \pm 0.09 a$ & $100 \pm 0.00 \mathrm{a}$ & $3.56 \pm 0.01 \mathrm{a}$ \\
\hline & $\mathrm{NaCl}$ & $80 \pm 5.77 b$ & $2.42 \pm 0.03 \mathrm{~d}$ & $80 \pm 10.00 \mathrm{abc}$ & $1.60 \pm 0.15 \mathrm{e}$ \\
\hline
\end{tabular}

Mean values were presented as means \pm SE. The significantly differences $(p \leq 0.05)$ of means are indicated by different letters.

\section{Effects of Spd priming on seedling growth}

Root length of normal seedlings produced from $\mathrm{H}_{2} \mathrm{O}$ and Spd priming were significantly longer than those from non-primed seeds under both normal and salt-stress conditions. When germinated under normal condition, root length of seedlings grown from seeds primed with $\mathrm{H}_{2} \mathrm{O}$, and 0.5, 1.0 and $1.5 \mathrm{mM} \mathrm{Spd}$ showed $35,38,43$ and $48 \%$ increase compared to root length of seedlings from non-primed seeds. Under $\mathrm{NaCl}$, root length of all priming treatments were longer than non-priming $(50,66,72$ and $81 \%$ longer) group. In deteriorated seeds germinated under control and $\mathrm{NaCl}$ stress conditions, priming with $\mathrm{H}_{2} \mathrm{O}$ and $\mathrm{Spd}$ also significantly increased root length compared to non-priming groups. Under normal condition, $\mathrm{H}_{2} \mathrm{O}$ priming increased $31 \%$ of root length while Spd priming at $0.5,1.0$ and $1.5 \mathrm{mM}$ increased 32, 44 and 50\%, respectively. When deteriorated seeds were germinated under $\mathrm{NaCl}$ stress, Spd priming groups promoted longer root length $(14,31$ and $43 \%$ increase in $0.5,1.0$ and $1.5 \mathrm{mM}$, respectively) compared to non-priming group (Figure 1A). 

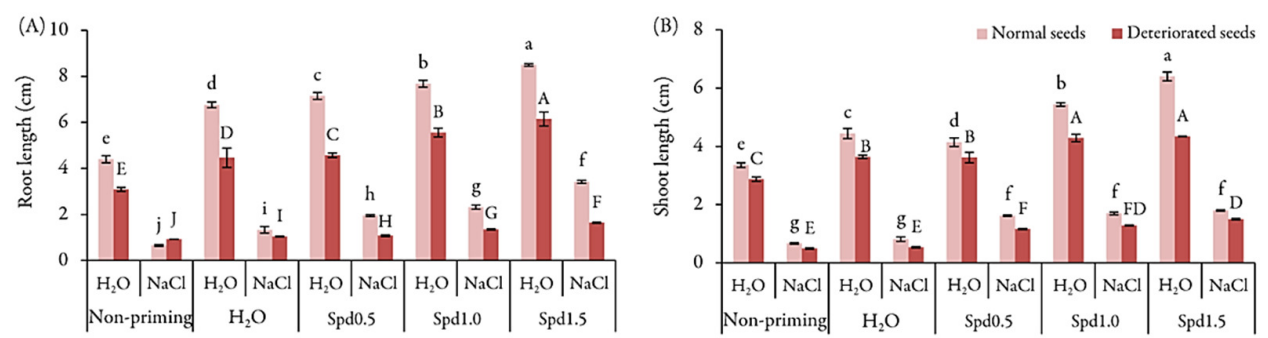

Figure 1. Root length (A) and shoot length (B) of seedlings established from normal (light bars) and deteriorated (dark bars) rice seeds germinated under normal $\left(\mathrm{H}_{2} \mathrm{O}\right)$ and stress $(\mathrm{NaCl})$ conditions for $10 \mathrm{~d}$ Seeds were non-primed, primed with $\mathrm{H}_{2} \mathrm{O}, 0.5 \mathrm{mM}, 1.0 \mathrm{mM}$ and $1.5 \mathrm{mM}$ Spd before germination. The values are means \pm SE. Different lower-case letters for normal seeds and capital letters for deteriorated seeds indicate that the means are significantly different $(p \leq 0.05)$

For shoot length, shoot length of $\mathrm{H}_{2} \mathrm{O}$ priming group was significantly higher than non-priming group under control condition ( $24 \%$ increase). In contrast, for seeds germinated under $\mathrm{NaCl}$ stress, $\mathrm{H}_{2} \mathrm{O}$ priming did not show beneficial effects to reduce $\mathrm{NaCl}$-induced growth inhibition in both normal and deteriorated seeds. Normal seeds primed with Spd in all concentrations and germinated under both control and salt treatment conditions showed longer shoot length than non-priming and $\mathrm{H}_{2} \mathrm{O}$-priming groups. Priming deteriorated seeds with Spd also promoted shoot length in both control and salt treatment conditions. Deteriorated seeds previously primed with Spd produced seedlings with markedly longer shoot length under control condition $(21,33$ and $34 \%$ increase in $0.5,1.0$ and $1.5 \mathrm{mM}$, respectively) and under $\mathrm{NaCl}$ stress $(58,62$ and $67 \%$ increase in $0.5,1.0$ and $1.5 \mathrm{mM}$, respectively) compared to non-priming groups (Figure $1 \mathrm{~B}$ ).

Priming normal seeds with $\mathrm{H}_{2} \mathrm{O}$ and Spd caused an increase in root dry weight of seedlings under nonstressed condition (increased: 28, 49, 51 and 64\% in $\mathrm{H}_{2} \mathrm{O}, 0.5 \mathrm{mM} \mathrm{Spd}, 1.0 \mathrm{mM}$ Spd and $1.5 \mathrm{mM}$ Spd groups, respectively). In contrast, for deteriorated seeds, only high concentration of $S p d(1.0$ and $1.5 \mathrm{mM} \mathrm{Spd}$ ) was able to enhance root dry weight (26 and 39\% increase). When stressed with $\mathrm{NaCl}$, normal seeds primed with 1.0 and $1.5 \mathrm{mM}$ Spd developed into seedlings having 41 and $35 \%$ higher root dry weight compared to non-priming group, while 56 and 69\% increase were observed for deteriorated seeds (Figure 2A).

No significant difference in shoot dry weight was found between seedlings grown under normal condition from non-primed and $\mathrm{H}_{2} \mathrm{O}$-primed normal seeds whereas Spd priming resulted in significantly increased shoot dry weight. When exposed to $\mathrm{NaCl}$, priming normal seeds with $\mathrm{H}_{2} \mathrm{O}$ enhanced seedling shoot dry weight (27\% increase) compared to those from non-primed seeds. Seeds primed with Spd also produced seedlings with higher shoot dry weight than non-primed seeds. The amounts of increase in shoot dry weight were 39,54 and $57 \%$ for priming with $0.5,1.0$ and $1.5 \mathrm{mM} \mathrm{Spd}$, respectively. For deteriorated seeds, priming with $\mathrm{H}_{2} \mathrm{O}$ was able to enhance shoot dry weight only under control condition (increased 14\%). Priming with Spd resulted in increased shoot dry weight (seeds treated with highest Spd concentration produced seedlings with highest shoot dry weight). Under salt stress, priming with $0.5 \mathrm{mM} \mathrm{Spd} \mathrm{showed} \mathrm{slightly} \mathrm{increased} \mathrm{shoot}$ dry weight compared to non-priming and $\mathrm{H}_{2} \mathrm{O}$ priming groups. However, this change was not statistically significant. Deteriorated seeds treated with 1.0 and $1.5 \mathrm{mM}$ Spd resulted in markedly increased seedling shoot dry weight (increased 38 and 64\%, respectively) compared to non-priming group (Figure 2B).

\section{Effects of Spd priming on $\mathrm{ROS}\left(\mathrm{O}_{2}{ }^{-}\right)$production}

For histological localization of $\mathrm{O}_{2}{ }^{*-}$ productions, normal and deteriorated dehusked seeds were stained with NBT. At $12 \mathrm{~h}$, it was found that all normal seeds in all priming and non-priming treatments were strongly stained with NBT under control condition. When seeds were germinated under $\mathrm{NaCl}$ stress, seeds primed with Spd showed stronger color of NBT staining than seed primed with $\mathrm{H}_{2} \mathrm{O}$ while no color development was observed in non-primed seeds. In deteriorated seeds, moderate intensity of NBT staining was found in seeds primed with Spd in both normal and salt stress conditions. For $\mathrm{H}_{2} \mathrm{O}$ priming, faint staining could be seen in 
seeds incubated under control condition, in contrast to seed germinated under salt treatment which showed no staining. For non-primed seeds, both seeds grown under normal and $\mathrm{NaCl}$ stress showed no NBT staining (Figure 3A).
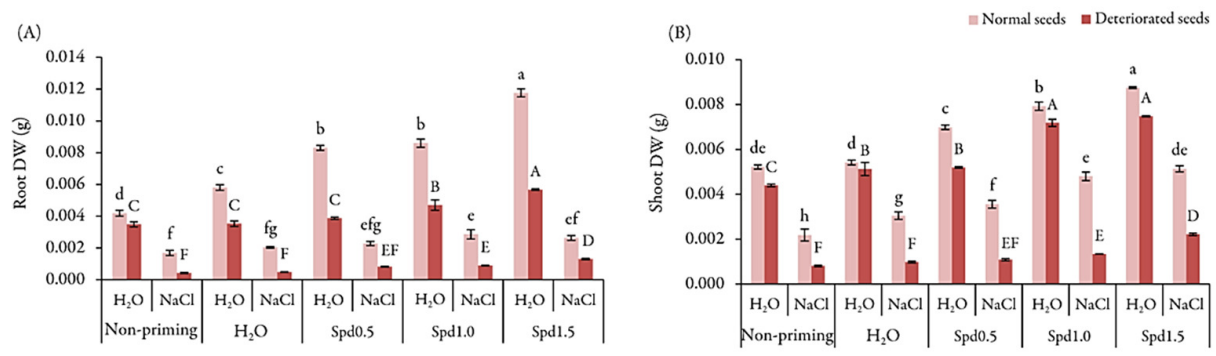

Figure 2. Root dry weight (A) and shoot dry weight (B) of seedlings established from normal (light bars) and deteriorated (dark bars) rice seeds germinated under normal $\left(\mathrm{H}_{2} \mathrm{O}\right)$ and stress $(\mathrm{NaCl})$ conditions for $10 \mathrm{~d}$

Seeds were non-primed, primed with $\mathrm{H}_{2} \mathrm{O}, 0.5 \mathrm{mM}, 1.0 \mathrm{mM}$ and $1.5 \mathrm{mM}$ Spd before germination. The values are means \pm SE. For details of statistical symbols, see Figure 1

(A)

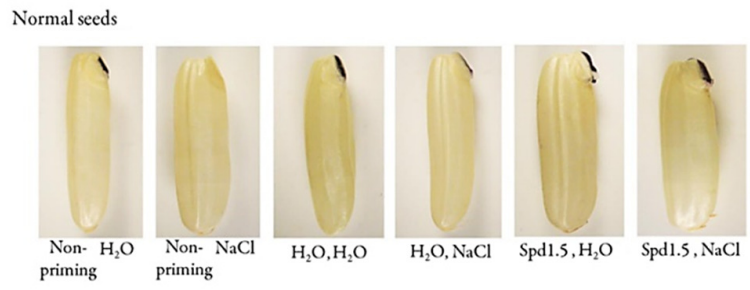

Deteriorated seeds
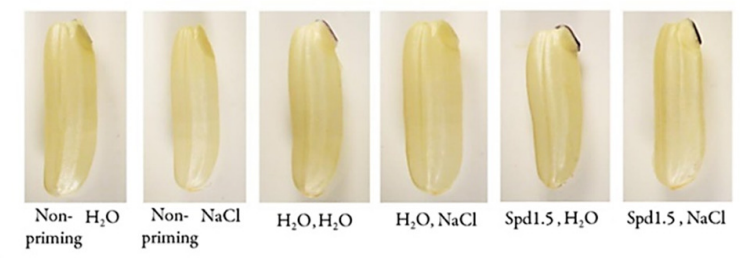

(B)

Normal seeds
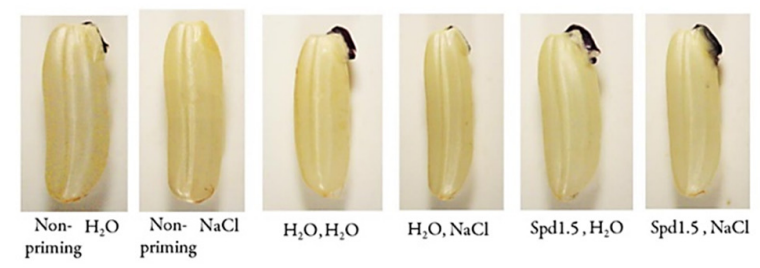

Deteriorated seeds
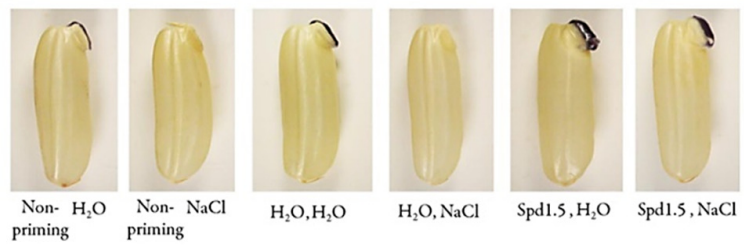

Figure 3. Histochemical localization of $\mathrm{O}_{2}{ }^{--}$in rice seeds imbibed for $12 \mathrm{~h}(\mathrm{~A})$ and $24 \mathrm{~h}(\mathrm{~B})$ by NBT staining 
At $24 \mathrm{~h}, \mathrm{NBT}$ staining was observed in embryos of all groups of normal seeds incubated under non-stress treatments. It was clearly seen that the strongest staining was found in Spd-primed seeds followed by $\mathrm{H}_{2} \mathrm{O}$ primed and non-primed seeds. In deteriorated seeds, high intensity of NBT staining was seen in seeds primed with Spd in both control and salt stress conditions. Under control condition, embryos of seedlings grown from Spd-primed seeds were more darkly stained than those from $\mathrm{H}_{2} \mathrm{O}$ priming and non-priming groups. Under $\mathrm{NaCl}$ condition, no NBT staining was observed in seeds primed with $\mathrm{H}_{2} \mathrm{O}$ priming and non-priming groups (Figure 3B).

At $36 \mathrm{~h}$, normal seeds primed with Spd and $\mathrm{H}_{2} \mathrm{O}$ imbibed under control condition developed coleoptile and radicle in contrast to seeds from non-priming group. Stronger color of NBT staining was observed in radicle while no staining appeared in the coleoptile. When seeds were exposed to salt stress, the highest intensity of NBT stain was found in embryos of seeds primed with Spd whereas faint stain was observed in embryos of seeds primed with $\mathrm{H}_{2} \mathrm{O}$ and non-primed seeds. For deteriorated seeds incubated under control condition, embryos were stained with NBT in all treatments with strongest color in the Spd-primed seed. Visible coleoptiles started to develop from seeds primed with Spd under both control and $\mathrm{NaCl}$ stress. Conversely, non-primed seeds incubated with $\mathrm{NaCl}$ showed no staining (Figure 4A).

At $48 \mathrm{~h}$, radicle protrusion and coleoptile emergence were found in normal seeds primed with $\mathrm{H}_{2} \mathrm{O}$ and Spd under non-stressed condition. It was clearly seen that radicles were well stained with NBT but coleoptiles were not. When seeds were incubated with $\mathrm{NaCl}$, the elongation of radicle and coleoptile only occurred in the Spd-primed seed. For deteriorated seeds grown under non-stressed condition, seedlings with radicles and coleoptiles were observed in $\mathrm{Spd}$ and $\mathrm{H}_{2} \mathrm{O}$ priming groups whereas no coleoptile emergence was found in nonpriming group. When seeds were germinated under $\mathrm{NaCl}$, radicle (stained) and coleoptile (unstained) began to emerge only from seeds primed with Spd (Figure 4B).

\section{Effects of Spd priming on membrane damage}

At $3 \mathrm{~d}$, seedlings from normal seeds primed with $\mathrm{H}_{2} \mathrm{O}$ or Spd showed significantly lower EL (decreased by $26 \%$ in both groups) compared to seedlings from non-primed seeds under control, and decreased by $21 \%$ in $\mathrm{H}_{2} \mathrm{O}$ priming and 24\% in Spd priming groups under $\mathrm{NaCl}$ stress conditions. For deteriorated seeds in both conditions, seedlings from seeds primed with Spd showed the lowest EL followed by those primed with $\mathrm{H}_{2} \mathrm{O}$. In comparison with the non-priming group, Spd priming resulted in 51 and $31 \%$ reduction in EL under control and stress conditions, respectively, while $\mathrm{H}_{2} \mathrm{O}$ priming showed 38 and $27 \%$ reduction (Figure 5A). At $10 \mathrm{~d}$, priming with $\mathrm{H}_{2} \mathrm{O}$ did not affect EL in seedlings from normal seeds germinated under normal and salt stress conditions. EL levels were considerably lower in seedlings produced from seeds primed with Spd (31 and 45\% reduction, respectively) compared to seedlings from non-primed seeds. For deteriorated seeds, no significant differences in EL were noticed between seedlings of $\mathrm{H}_{2} \mathrm{O}$ priming and non-priming groups under non-stressed condition. However, significant differences were found under $\mathrm{NaCl}$ stress (EL of seedlings of $\mathrm{H}_{2} \mathrm{O}$ priming group was 9\% lower). EL decreased markedly in seedlings grown from seeds primed with Spd compared to other groups in both normal and salt stress conditions. It was found that Spd priming caused 36 and $32 \%$ lower in seedling EL compared to non-priming groups under control and $\mathrm{NaCl}$ stress, respectively (Figure 5B).

MDA is an indicator of lipid peroxidation caused by oxidative stress. At $3 \mathrm{~d}$, normal seeds primed with both $\mathrm{H}_{2} \mathrm{O}$ and Spd produced seedlings with lower MDA content under control condition (decreased by 28 and $78 \%$, respectively compared with seedlings from non-primed seeds). Spd priming resulted in significant decline (15\%) in MDA under salt stress compared to non-priming group. In contrast, differences in seedling MDA content were not significant among non-priming, $\mathrm{H}_{2} \mathrm{O}$ priming and Spd priming treatments in deteriorated seeds under salt stress (Figure 5C). At $10 \mathrm{~d}$ under non-stressed and salt stress conditions, it was noted that MDA content of seedlings from normal seeds treated with Spd was lowest (decreased by 54 and $66 \%$, respectively) compared to non-priming groups. For deteriorated seeds, Spd priming seeds produced seedlings having 41 and $83 \%$ lower MDA than $\mathrm{H}_{2} \mathrm{O}$ priming and non-priming groups under non-stressed 
condition. Similarly, under $\mathrm{NaCl}$ stress, seedlings from Spd-primed seeds had 48 and 79\% lower MDA than those of $\mathrm{H}_{2} \mathrm{O}$ priming and non-priming groups (Figure 5D).

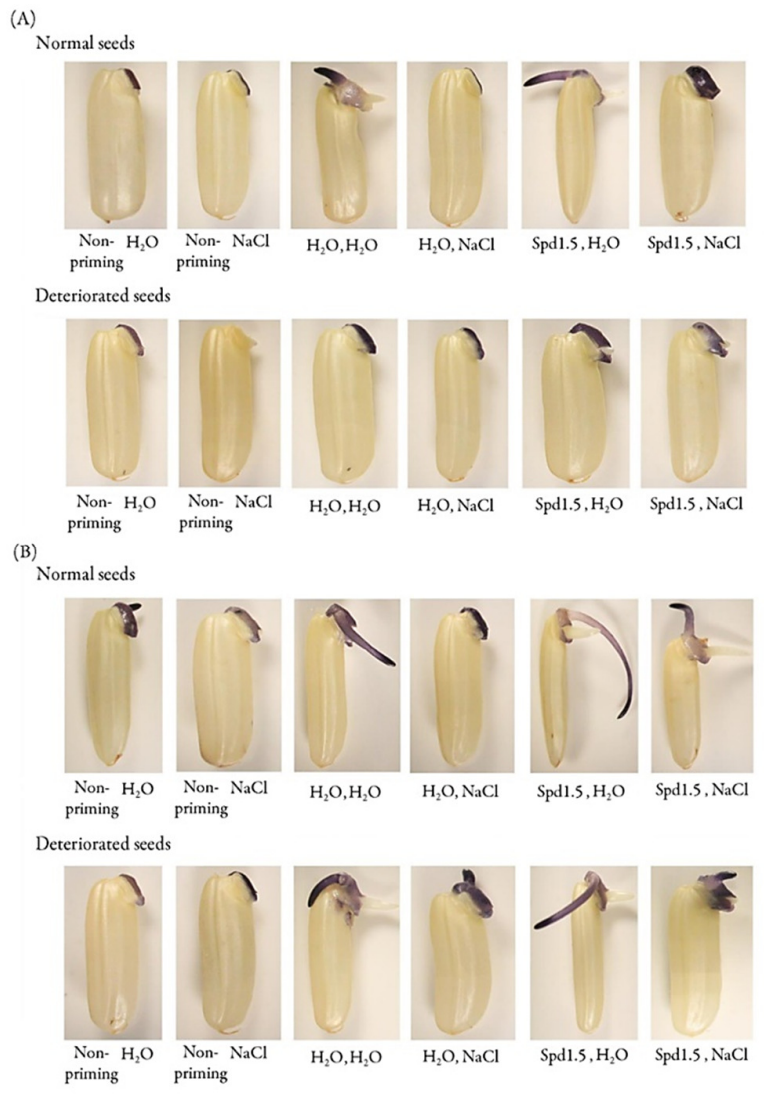

Figure 4. Histochemical localization of $\mathrm{O}_{2}{ }^{--}$in rice seeds imbibed for $36 \mathrm{~h}(\mathrm{~A})$ and $48 \mathrm{~h}$ (B) by NBT staining
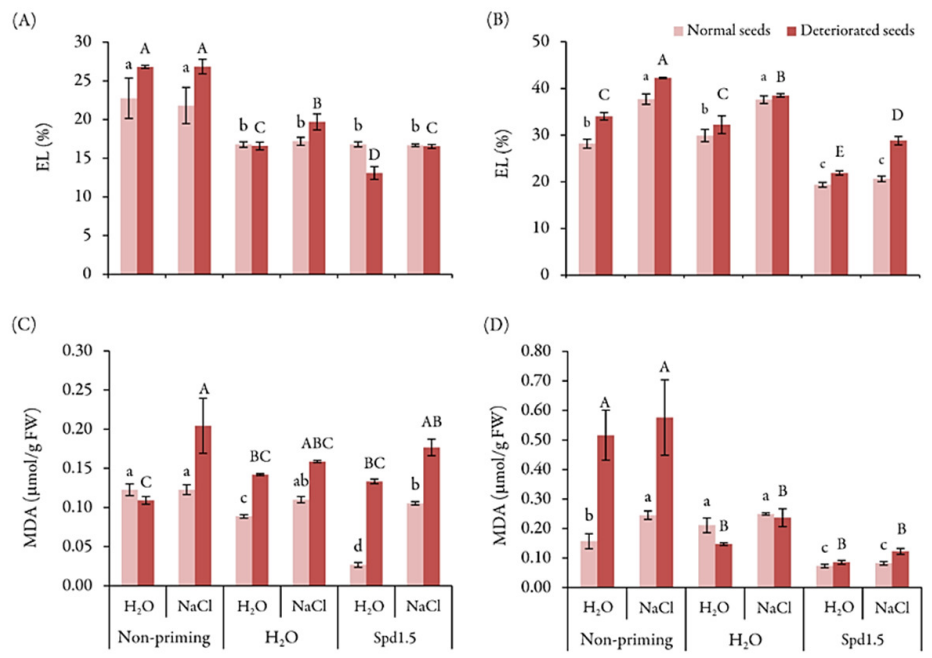

Figure 5. EL of seedlings aged $3 \mathrm{~d}(\mathrm{~A})$ and $10 \mathrm{~d}(\mathrm{~B}) ;$ MDA content of seedlings aged $3 \mathrm{~d}(\mathrm{C})$ and $10 \mathrm{~d}(\mathrm{D})$. Seedlings were established from normal (light bar) and deteriorated (dark bar) rice seeds Seeds were non-primed, primed with $\mathrm{H}_{2} \mathrm{O}$ and $1.5 \mathrm{mM}$ Spd before germination. The values are means $\pm S E$. For details of statistical symbols, see Figure 1 


\section{Discussion}

It is known that deteriorated seeds have poor germination rate and seedling establishment. Not only seed physiology factor, environmental factors such as salinity or dehydration also exacerbate seed germination and seedling growth. This research aimed to study the effects of priming normal and deteriorated KDML105 seeds with Spd on germination and physiological changes of seedlings under salt stress. Salt stress limits seed germination and seedling growth. In addition, deteriorated seeds lost their ability to germinate. Salt stress causes more negative effects on seed germination and seedling growth in seeds or seedling established from deteriorated seeds than normal seeds (Table 1). Priming normal seeds with $\mathrm{H}_{2} \mathrm{O}$ or Spd resulted in better seed germination and seedling growth when seed germinated under control condition. Similarly, priming normal seed with $\mathrm{H}_{2} \mathrm{O}$ or Spd was able to improve seed germination under salt stress (Table 1). These results indicated that seed priming (either $\mathrm{H}_{2} \mathrm{O}$ or Spd) gave beneficial effects to promote germination. Seed hydropriming was reported to improve germination velocity and uniformity of Chenopodium quinoa and Amaranthus caudatus, resulted in high GP, high GI and reduced mean germination time under salinity (Moreno et al., 2018). Seed priming also promoted seedling growth under salt stress with Spd as the more effective priming agent than water (Figure 1 and Figure 2). For deteriorated seeds, $\mathrm{H}_{2} \mathrm{O}$ priming did not promote seed germination in both non-stressed and salt-stressed treatments which are different from Spd (Table 1). $\mathrm{H}_{2} \mathrm{O}$ priming was beneficial for seedling growth only under control condition while influence of Spd priming resulted in increased seedling growth under both conditions (Figure 1 and Figure 2). It is clearly seen that Spd is better priming agent than $\mathrm{H}_{2} \mathrm{O}$ not only for reducing adverse effects of salt stress but also superiority for stimulating germination of deteriorated seed and enhancing seedling growth. Similar to the finding of Chunthaburee et al. (2014) who reported that Spd priming improved growth of rice seedlings when plants were exposed to $\mathrm{NaCl}$ stress. Application of Spd has been demonstrated to ameliorate salinity stress effects on many plants such as rice, Kentucky blue grass and Zoysia grass (Roychoudhury et al., 2011; Puyang et al., 2015; Li et al., 2016).

Salinity stress elevates cellular ROS production. Balance between ROS and antioxidative defence system is important for reducing cellular damage and maintaining required ROS level essential for cell signalling (Munns and Tester, 2008). Histochemical localization of ROS by staining with NBT to detect $\mathrm{O}_{2}{ }^{*}$ (for localization of $\mathrm{H}_{2} \mathrm{O}_{2}$ see Supplementary File) found that $\mathrm{H}_{2} \mathrm{O}_{2}$ and $\mathrm{O}_{2}{ }^{*}$ were generated faster in normal seeds primed with Spd than other groups during 12-24 h after hydration under both control and $\mathrm{NaCl}$ stress (Figure 3). This ROS detection could be associated with faster germination of Spd-primed seeds as suggested by several reports. Huang et al. (2017) presented that the mechanism underlying the effects of Spd priming on acceleration of seed germination was probably related to $\mathrm{Spd}$ induction of high rate of $\mathrm{H}_{2} \mathrm{O}_{2}$ generation in the radicle via Spd oxidation. Moreover, Chen et al. (2016) proposed that polyamine oxidase-induced $\mathrm{H}_{2} \mathrm{O}_{2}$ production during seed imbibition was involved in promoting seed germination. Ishibashi et al. (2015) suggested that $\mathrm{H}_{2} \mathrm{O}_{2}$ (or other ROS molecules) could play a role as oxidative signalling and stimulate radicle protrusion process. Similarly, early generation of ROS of Spd-primed deteriorated seeds was coincided with earlier germination (Figure 3 and Figure 4; Supplementary File). It is believed that ROS was involved in endosperm weakening leading to emergence of coleoptile and radicle (Gomes and Garcia, 2013). Some seeds in $\mathrm{H}_{2} \mathrm{O}$ priming and non-priming also produced $\mathrm{ROS}$ in the early stage of hydration under salt stress (Figure 3 and Figure 4; Supplementary File). However, those seeds were unable to germinate or germinate slower. These may be because excessive ROS level was accumulated leading to inhibition of seed germination process. Although ROS are key factor stimulating seed germination, when seeds are germinated under abiotic stress excessive ROS can become harmful molecules (Kumar et al., 2015).

Under several types of abiotic stresses including salt, EL and MDA occur inevitably by oxidative stress. Less membrane damage contributes to salt tolerance ability (Wu et al., 2017). Seedlings of normal and deteriorated seeds produced via Spd priming showed less effects of oxidative damage while $\mathrm{H}_{2} \mathrm{O}$ priming was able to mitigate membrane damage at only the beginning period of seedling establishment (3-d-old seedlings). However, priming with $\mathrm{Spd}$ or $\mathrm{H}_{2} \mathrm{O}$ effectively reduced salt stress effects in young seedlings as compared with 
non-priming suggesting that priming seeds could induce stress tolerance (Figure 5). Parvin et al. (2014) reported that during salinity stress, application of Spd showed protective roles in reducing the intensity of oxidative stress. Many studies have demonstrated that priming seeds with Spd resulted in salt stress tolerance by alleviating stress injury caused by oxidative damages to near-normal condition (Puyang et al., 2015; Zhang et al., 2016; Paul et al., 2017). Overall, decreasing salt stress injury in seedlings was more pronounced when seeds were primed with Spd than $\mathrm{H}_{2} \mathrm{O}$.

\section{Conclusions}

Priming seeds with $\mathrm{H}_{2} \mathrm{O}$ or Spd resulted in better seed germination compared to non-priming. The result showed that $1.5 \mathrm{mM}$ Spd was the best concentration for priming to promote seed germination and seedling growth. During salt treatment, Spd priming resulted in increasing seed germination, improving seedling growth and alleviating oxidative stress in seedlings. In addition, Spd promoted germination of deteriorated seeds, increased seedling growth and decreased membrane damage in both non-stressed and saltstressed conditions. Thus, priming seeds with Spd stimulated seed acclimation leading to promote seed germination and reduced salt stressed damages in rice seedlings under salt stress.

\section{Authors' Contributions}

Conceptualization: PT; Data curation; NN and NK; Formal analysis: NN and NK; Funding acquisition: PT; Investigation: NN, NK and PT; Methodology: NN and NK; Project administration: PT; Resources: PT; Supervision: PT; Validation: PT; Visualization: PT; Writing - original draft: NN and NK; Writing - review and editing: NN and PT. All authors read and approved the final manuscript.

\section{Acknowledgements}

This work was supported by the Research and Technology Transfer Affairs, Khon Kaen University (Fiscal year 2017) and scholarship under the Post-doctoral Program from Research Affairs and Graduate School, Khon Kaen University (58331). We thank Dr. Wuttipong Mahakham (Department of Biology, Faculty of Science, Khon Kaen University) for his suggestions on histochemical localization technique.

\section{Conflict of Interests}

The authors declare that there are no conflicts of interest related to this article.

\section{References}

Bailly C, El-Maarouf-Bouteau H, Corbineau F (2008). From intracellular signaling networks to cell death: the dual role of reactive oxygen species in seed physiology. Comptes Rendus Biologies 331(10):806-814. https://doi.org/10.1016/j.crvi.2008.07.022

Chen BX, Li WY, Gao YT, Chen ZJ, Zhang WN, Liu QJ, ... Liu J (2016). Involvement of polyamine oxidase-produced hydrogen peroxide during coleorhiza- limited germination of rice seeds. Frontiers in Plant Science 7:1219. https://doi.org/10.3389/fpls.2016.01219 
Chen K, Arora R (2013). Priming memory invokes seed stress-tolerance. Environmental and Experimental Botany 94: 33-45. https://doi.org/10.1016/j.envexpbot.2012.03.005

Chhetri S (2009. Identification of accelerated aging conditions for seed vigor test in rice (Oryza sativa L.). MSc Thesis, Suranaree University of Technology.

Chunthaburee S, Sanitchon J, Pattanagul W, Theerakulpisut P (2014). Alleviation of salt stress in seedlings of black glutinous rice by seed priming with spermidine and gibberellic acid. Notulae Botanicae Horti Agrobotanici ClujNapoca 42(2):405-413. https://doi.org/10.15835/nbha4229688

Demidchik V, Straltsova D, Medvedev SS, Pozhvanov GA, Sokolik A, Yurin V (2014). Stress-induced electrolyte leakage: the role of $\mathrm{K}^{+}$permeable channels and involvement in programmed cell death and metabolic adjustment. Journal of Experimental Botany 65(5):1259-1270. https://doi.org/10.1093/jxb/eru004

El-Maarouf-Bouteau H, Bailly C (2008). Oxidative signaling in seed germination and dormancy. Plant Signaling \& Behavior 3(3):175-182. https://doi.org/10.4161/psb.3.3.5539

Esfandiari E, Gohari G (2017). Response of ROS-scavenging systems to salinity stress in two different wheat (Triticum aestivum L.) cultivars. Notulae Botanicae Horti Agrobotanici Cluj-Napoca 45(1):287-291. https://doi.org/10.15835/nbha45110682

Gill SS, Tuteja N (2010a). Reactive oxygen species and antioxidant machinery in abiotic stress tolerance in crop plants. Plant Physiology and Biochemistry 48(12):909-930. https://doi.org/10.1016/j.plaphy.2010.08.016

Gill SS, Tuteja N (2010b). Polyamines and abiotic stress tolerance in plants. Plant Signaling \& Behavior 5(1):26-33. https://doi.org/10.4161/psb.5.1.10291

Gomes MP, Garcia QS (2013). Reactive oxygen species and seed germination. Biologia 68:351-357. https://doi.org/10.2478/s11756-013-0161-y

Heath RL, Packer L (1968). Photoperoxidation in isolated chloroplasts. I. Kinetics and stoichiometry of fatty acid peroxidation. Archives of Biochemistry and Biophysics 125(1):189-198. https://doi.org/10.1016/0003-9861(68)90654-1

Huang Y, Lin C, He F, Li Z, Guan Y, Hu Q, Hu J (2017). Exogenous spermidine improves seed germination of sweet corn via involvement in phytohormone interactions, $\mathrm{H}_{2} \mathrm{O}_{2}$ and relevant gene expression. BMC Plant Biology 17: 1. https://doi.org/10.1186/s12870-016-0951-9

Hussain S, Zheng M, Khan F, Khaliq A, Fahad S, Peng S, ... Nie L (2015). Benefits of rice seed priming are offset permanently by prolonged storage and the storage conditions. Scientific Reports 29(5):8101. https://doi.org/10.1038/srep08101

Ishibashi Y, Kasa S, Sakamoto M, Aoki N, Kai K, Yuasa T, ... Iwaya-Inoue M (2015). A role for reactive oxygen species produced by NADPH oxidases in the embryo and aleurone cells in barley seed germination. PLoS One 10(11):e0143173. https://doi.org/10.1371/journal.pone.0143173

Jisha KC, Puthur JT (2016). Seed priming with beta-amino butyric acid improves abiotic stress tolerance in rice seedlings. Rice Science 23(5):242-254. https://doi.org/10.1016/j.rsci.2016.08.002

Jyoti, Malik CP (2013). Seed Deterioration: A Review. International Journal of Life science and Pharma Research 2(3):374-385.

Kreslavski VD, Los DA, Allakhverdiev SI, Kuznetsov VIV (2012). Signaling role of reactive oxygen species in plants under stress. Russian Journal of Plant Physiology 59:141-154. https://doi.org/10.1134/S1021443712020057

Kumar SPJ, Prasad SR, Banerjee R, Thammineni C (2015). Seed birth to death: dual functions of reactive oxygen species in seed physiology. Annals of Botany 116(4):663-668. https://doi.org/10.1093/aob/mcv098

Li S, Jin H, Zhang Q (2016). The effect of exogenous spermidine concentration on polyamine metabolism and salt tolerance in Zoysiagrass (Zoysia japonicaSteud) subjected to short-term salinity stress. Frontiers in Plant Science 17:1221. https://doi.org/10.3389/fpls.2016.01221

Liu M, Chu M, Ding Y, Wang S, Liu Z, Tang S, ... Li G (2015). Exogenous spermidine alleviates oxidative damage and reduce yield loss in rice submerged at tillering stage. Frontiers in Plant Science 31:919. https://doi.org/10.3389/fpls.2015.00919

Miller G, Suzuki N, Ciftci-Yilmaz S, Mittler R (2010). Reactive oxygen species homeostasis and signalling during drought and salinity stresses. Plant, Cell \& Environment 33(4):453-637. https://doi.org/10.1111/j.1365-3040.2009.02041.x

Moreno C, Seal CE, Papenbrock J (2018). Seed priming improves germination in saline conditions for Chenopodium quinoa and Amaranthus caudatus. Journal of Agronomy and Crop Science 204(1):40-48. https://doi.org/10.1111/jac.12242 
Munns R, Tester M (2008). Mechanisms of salinity tolerance. Annual Review of Plant Biology 59:651-681. https://doi.org/10.1146/annurev.arplant.59.032607.092911

Parvin S, Ran O, Sathiyaraj G, Khorolragchaa A, Kim Y, Yang, D (2014). Spermidine alleviates the growth of salinestressed ginseng seedlings through antioxidative defense system. Gene 537(1):70-78. https://doi.org/10.1016/j.gene.2013.12.021

Paul S, Roychoudhury A, Banerjee A, Chaudhuri N, Ghosh P (2017). Seed pre-treatment with spermidine alleviates oxidative damages to different extent in the salt $(\mathrm{NaCl})$-stressed seedlings of three indica rice cultivars with contrasting level of salt tolerance. Plant Gene 11:112-123. https://doi.org/10.1016/j.plgene.2017.04.002

Paul S, Roychoudhury A (2017). Seed priming with spermine and spermidine regulates the expression of diverse groups of abiotic stress-responsive genes during salinity stress in the seedlings of indica rice varieties. Plant Gene 11:124132. https://doi.org/10.1016/j.plgene.2017.04.004

Puyang X, An M, Han L, Zhang X (2015). Protective effect of spermidine on salt stress induced oxidative damage in two Kentucky bluegrass (Poa pratensis L.) cultivars. Ecotoxicology and Environmental Safety 117:96-106. https://doi.org/10.1016/j.ecoenv.2015.03.023

Roychoudhury A, Basu S, Sengupta DN (2011). Amelioration of salinity stress by exogenously applied spermidine or spermine in three varieties of indica rice differing in their level of salt tolerance. Journal of Plant Physiology 168:317-328. https://doi.org/10.1016/j.jplph.2010.07.009

Salah SM, Yajing G, Dongdong C, Jie L, Aamir N, Qijuan H, ... Jin H (2015). Seed priming with polyethylene glycol regulating the physiological and molecular mechanism in rice (Oryza sativa L.) under nano-ZnO stress. Scientific Reports 30:14278. https://doi.org/10.1038/srep14278v

Sofo A, Scopa A, Nuzzaci M, Vitti A (2015). Ascorbate peroxidase and catalase activities and their genetic regulation in plants subjected to drought and salinity stresses. International Journal of Molecular Sciences 16(6):1356113578. https://doi.org/10.3390/ijms160613561

Theerakulpisut P, Kanawapee N, Panwong B (2016). Seed priming alleviated salt stress effects on rice seedlings by improving $\mathrm{Na}^{+} / \mathrm{K}^{+}$and maintaining membrane integrity. International Journal of Plant Biology 7(6402):53-58. https://doi.org/10.4081/pb.2016.6402

Wu W, Zhang Q, Ervin EH, Yang Z, Zhang X (2017). Physiological mechanism of enhancing salt stress tolerance of perennial ryegrass by 24-Epibrassinolide. Frontiers in Plant Science 8:1017. https://doi.org/10.3389/fpls.2017.01017

You J, Chan Z (2015). ROS regulation during abiotic stress responses in crop plants. Frontiers in Plant Science 6:1092. https://doi.org/10.3389/fpls.2016.01536

Zhang N, Shi X, Guan Z, Zhao S, Zhang F, Chen S, ... Chen F (2016). Treatment with spermidine protects chrysanthemum seedlings against salinity stress damage. Plant Physiology and Biochemistry 105:260-270. https://doi.org/10.1016/j.plaphy.2016.05.002

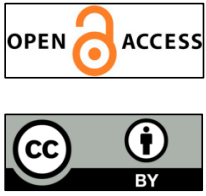

The journal offers free, immediate, and unrestricted access to peer-reviewed research and scholarly work. Users are allowed to read, download, copy, distribute, print, search, or link to the full texts of the articles, or use them for any other lawful purpose, without asking prior permission from the publisher or the author.

License - Articles published in Notulae Botanicae Horti Agrobotanici Cluj-Napoca are Open-Access, distributed under the terms and conditions of the Creative Commons Attribution (CC BY 4.0) License. (C) Articles by the authors; UASVM, Cluj-Napoca, Romania. The journal allows the author(s) to hold the copyright/to retain publishing rights without restriction. 